УДК 621.311

DOI https://doi.org/10.32838/2663-5941/2021.2-2/12

Олійник Ю.С.

Українська інженерно-педагогічна академія

\title{
Лазарчук Л.М.
}

Київський енергетичний фаховий коледж

Сук I.B.

Київський енергетичний фаховий коледж

\section{НОВІ ТЕНДЕНЦІї В ЕНЕРГЕТИЦІ}

Коли ми вживаємо словосполучення «інтелектуальні мережі», то маємо на увазі нові засади роботи енергетичної галузі. У статті розглянуто нові тенденції в енергетиці, а саме приділено увагу аналізу основних функиій, переваг та недоліків інтелектуальних адаптивних мереж технологіï SmartGrid. Основна мета інтелектуальних мереж полягає у забезпеченні надійного використання мереж, збільшення строку служби та можсливості всебічного контролю електричних апаратів на відстані. Робота інтелектуальних мереж здійснюється на основі інформаційно-комунікаційних технологій з метою подальшої економії фінансових витрат та збільшення рівня надійності електричних мереж без залучення додаткових паливно-енергетичних ресурсів. Сучасні енергетичні системи повинні бути модернізовані відповідно до нових тенденцій розвитку електроенергетичної галузі. У прочесі оптимізаціі сучасних енергетичних систем є можливість збільшення їх ефективності, при цьому відсутні потреби у значних капіталовкладеннях у процес виробництва, передачі та розподілу електричної енергії. Тобто можливо модернізувати наявну систему до інтелектуальної, тим самим створивщи повною мірою інтегровану систему виробнищтва, передачі, розподілу та споживання електричної енергії, наприклад, побутовими споживачами. Стисло розглянуто основні групи елементів, що входять до складу інтелектуальних мереж. Оскільки інтелектуальні мережі SmartGrid є досить новою тенденцією та не є розповсюдженими, ие означає, щңо не повною мірою визначено їх вплив на якість електричної енергії у споживача. Стаття дуже стисло розглядає вплив використання нових інтелектуальних мереж на якість електричної енергії. Також у статті приділено увагу американському підходу щодо стандартів взаємодії для SmartGrid, очікування від втілення інтелектуальних мереж.

Ключові слова: інтелектуальні мережі, надійність електромереж, електрична енергія, розподільчі мережі, енергетичні ресурси, відновлювальні джерела енергії.

Постановка проблеми. Відносно новою тенденцією $є$ швидкий розвиток інтелектуальних адаптивних мереж в енергетиці, які мають значні перспективи. Ці інтелектуальні мережі відомі також під назвою «SmartGrid». Ця технологія відома як Self-Monitoring Analysis and Reporting Technology. Якщо проаналізувати походження цих мереж, то необхідно зауважити, що вони заявили про себе ще у минулому столітті в Радянському Союзі та в інших державах.

Національна енергетична компанія «Укренерго» зазначає: «Нами розпочато роботу над застосуванням у національній енергосистемі новітніх революційних технологій. Нині ми активно працюємо над підготовкою до впровадження в країні системи інтелектуальних мереж SmartGrid. У світі ця інтелектуальна мережа дає змогу підвищити ефективність та надійність_електропостачання, значно зростає рівень безвідмов- ної роботи систем та зберігається навколишне середовище» [8].

У сучасному світі інтелектуальними мережами можна вважати саме ті мережі, які базуються на інформаційно-комунікативних технологіях, які дають змогу отримати своєчасний звіт щодо виробництва та подальшого використання електричної енергії. Все це дає змогу споживачам електричної енергії створювати такі виробництва, які можуть здійснювати економію коштів, функціонувати $з$ підвищеною надійністю та не вимагати додаткового використання енергетичних ресурсів.

Аналіз останніх досліджень і публікацій. У 2010 році Національним інститутом стандартизації та технології в США було опубліковано документ, який регламентував сумісність, стандарти SmartGrid та дорожню карту. Відповідно до цього документу «інтелектуальна мережа - це складна підсистема системи, яка повинна широко 
розподіляти поняття ï основних блоків та того, яким чином вони пов'язані між собою».

Було визначено вісім галузей, що мали першочергові пріоритети. До них, згідно з [2, с. 27], належать:

- реагування на попит та енергоефективність споживачів;

- широка ситуаційна обізнаність;

- зберігання електроенергії;

- розширена інфраструктура вимірювань;

- управління розподільчою мережею;

- кібербезпека;

- мережеві комунікації [2, с. 27].

Щодо розвитку інтелектуальних мереж SmartGrid у країнах світу, то необхідно зауважити, що за передумовами ринкових експертів до 2030 року населення буде споживати вдвічі більше електричної енергії, ніж натепер [7].

Країни Європейського союзу планують знизити споживання електричної енергії через підвищення рівня енергоефективності, зокрема, широко використовуючи інтелектуальні мережі технологіï SmartGrid. Отже, впровадження та використання таких технологій дасть змогу знизити витрати енергетичних ресурсів [7].

Постановка завдання. Мета статті - проаналізувати поняття SmartGrid: які функції виконують нові інтелектуальні мережі, які мають переваги та недоліки. Стисло розглянути перспективи подальшого використання, зокрема в електричних мережах України. Розглянути, яким чином впливає застосування цих мереж на якість електричної енергії, що отримує споживач.

Виклад основного матеріалу. Як зауважено у документі «GRID 2030 A National Vision for Electricity's Second 100 Years», електроенергетична система у майбутньому базуватиметься на тій енергетичній системі, що існує зараз. Типи основного електричного обладнання, яке сьогодні застосовується у всіх системах електропостачання, лінії електропередач, трансформатори тощо у майбутньому будуть мати такі ж самі функції. При цьому фахівці зауважили, що втілення нових технологій, методів та інструментів дасть змогу суттєво підвищити ефективність, якість та безпеку існуючих енергетичних систем та у подальшому розробити нову конфігурацію електричних мереж. Результат цих взаємодій - це покращення ефективності поставок електричної енергії та проведення ринкових операцій, а також наявність мережі високої якості, що здатна забезпечити безпечні джерела електричної енергії, зокрема, у США» [3, с. 27].
Нині термін SmartGrid є таким, що набуває популярності та швидкого розповсюдження. Існує велика кількість визначень цього терміна, деякі 3 них $є$ близькими за значенням, деякі мають відмінності. Але при цьому незалежно від конкретного визначення інтелектуальні мережі нового покоління повинні виконувати найважливіші функції, серед яких необхідно визначити такі, як:

- керування процесом виробництвом електричної енергії та процесом її споживання;

- отримання інформації у повному обсязі від виробників електричної енергії щодо ії генерації;

- отримання інформації у повному обсязі щодо витрат електричної енергії.

Якщо звернутися до вітчизняних компаній, які свою діяльність присвячують технологіям SmartGrid, можна зауважити таке: «система SmartGrid - це система, яка повною мірою є інтегрованою, такою, що має можливості для саморегулювання та відновлювання. Вона містить генеруючі джерела, магістральні та розподільчі мережі, всі типи електроспоживачів, які керуються загальною мережею інформаційно-керуючих пристроїв у режимі реального часу» $[1 ; 2$, с. 35$]$.

Основні групи, які входять до складу SmartGrid, містять такі елементи, як [1; 3, с. 23]:

- інтелектуальні датчики інформації, контрольно-вимірювальні прилади, прилади обліку та контролю;

- системи збору та передачі інформації, які містять інтелектуальні пристрої та аналітичні інструменти для підтримки комунікацій на рівні об'єктів енергосистеми;

- інтелектуальні системи прогнозування, підтримки та прийняття рішень;

- удосконалені технології та активні силові компоненти електричної мережі;

- інтегровані системи інформаційного обміну.

Відповідно до [9, с. 16] конструктивні особливості та функції інтелектуальних мереж такі:

- моделі зносу компонентів - програмне забезпечення для прогнозування зносу забезпечує надійність; моделі перевіряються за допомогою результатів, що отримані у споживачів;

- робота обладнання, тобто датчиків та інших інтелектуальних пристроїв збору даних, повинна відповідати експлуатаційним характеристикам та технічним вимогам;

- можливість визначення тенденції щодо виробництва та технічного обслуговування систем та обладнання;

- використання нових методів експлуатації та технічного обслуговування енергетичного 
обладнання, зменшення втрат електричної енергії та зменшення перевантаження ліній електропередач;

- автоматичне сповіщення про виникнення проблем у процесі експлуатації обладнання оператору або автоматизованій системи управління щодо подальшого прийняття рішення.

Якщо проаналізувати використання інтелектуальних електричних мереж, можна зробити висновок, що воно тісно пов'язане із якістю електричної енергії. Має сенс подальший аналіз обліку якості електричної енергії під час використання інтелектуальних мереж SmartGrid: роздільно чи разом розглядаються питання щодо нормування якості електричної енергії під час використання інтелектуальних мереж. Застосування принципово нових електричних мереж має на увазі використання нового обладнання, те, який вплив на мережу загалом та на показники якості електричної енергії конкретно можуть здійснювати інтелектуальні мережі нового покоління - позитивний чи негативний. Проблеми споживачів електричної енергії знаходять відображення у технологіях SmartGrid. Як відомо, постійно зростаючі тарифи $\epsilon$ неабиякою проблемою для споживачів. Ці технології мають можливості для зниження витрат споживачів енергії.

Розглядають можливість розділення тарифів у часі тривалістю 15 хвилин та споживання електричної енергії за низькими тарифами. Це можливо за рахунок втілення мікропроцесорної техніки у побутові прилади. Мікропроцесорна техніка отримує інформацію про постачальника електричної енергії у часі та про тарифи $\mathrm{i}$, як наслідок, змінює споживання електричної енергії побутовим приладом таким чином, щоб воно у відповідний час було мінімальне. Використання таких побутових приладів дозволить споживачам знизити споживання електричної енергії у середньому на $5 \%$.

Як відомо, в режимі пікового навантаження споживачів здійснюється негативний вплив на режим роботи електрообладнання. Для того, щоб уникнути таких ситуацій, необхідно збільшити запас потужності, що може призвести до підвищення споживання паливно-енергетичних ресурсів та, як наслідок, до збільшення негативного впливу на навколишнє середовище. Це досить вагомий аргумент для пошуку альтернативних рішень щодо оптимізації цієї ситуації. Висока надійність систем електропостачання завжди була пріоритетним напрямом розвитку енергетики. Електричні мережі, які застосовують технологію SmartGrid, iз часом отримують більш широке застосування, i це є досить об'єктивним процесом. За допомогою використання інтелектуальних мереж можливо розв'язати або наблизитися до розв'язання таких завдань, як:

- зниження зростаючого споживання паличноенергетичних ресурсів;

- зменшення втрат в енергетичних мережах;

- зменшення рівня забрудненості навколишнього середовища, використання альтернативних джерел живлення [4, с. 221].

Завдання, що повинні бути розв'язані за допомогою інтелектуальних мереж, можна розглядати 3 погляду енергетичних компаній та споживачів електричної енергії. Кожна з цих груп переслідує свої конкретні завдання.

Отже, енергетичні компанії зі свого боку ставлять такі цілі, як:

- керування нерівномірністю графіків електричного навантаження;

- підвищення рівня оплати за електричну енергію, що було спожито;

- підвищення рівня ефективності керування;

- зниження втрат енергетичних ресурсів;

- підвищення надійності функціонування елементів енергетичної системи у випадку аварійних ситуацій у мережі;

- підвищення якості об'єднання елементів відновлювальної енергетики та розподільної генерації у системі.

3 боку споживачів електричної енергії інтелектуальні мережі технології SmartGrid повинні вирішувати такі завдання, як:

- підвищення ефективності роботи енергетичної системи;

- покращення доступу споживача до енергетичної інфраструктури;

- підвищення надійності електропостачання споживачів всіх категорій з безперебійності;

- сучасні підходи щодо повноцінної взаємодії споживачів із постачальниками електричної енергії;

- здатність електричної мережі до самовідновлення після перерви в електропостачанні;

- підвищення можливостей щодо керування процесом електропостачання та зниження оплати за електричну енергію, яку було спожито [1;9].

Як відомо, до основних вимог, які висуваються до систем електропостачання, належать:

- надійність електропостачання;

- безпека функціонування;

- економічність;

- можливість подальшого розширення;

- екологічність. 
Розглядаючи поступове та водночас широке втілення інтелектуальних мереж, необхідно зазначити їх переваги, які у своїй більшості є близькими до основних вимог щодо систем електропостачання, такі як [10, с. 162]:

- надійність та якість електропостачання - необхідно уникнути відключення споживачів електричної енергії від джерела та забезпечити споживання електричної енергії відповідної якості;

- безпека - забезпечення безпеки функціонування електричних мереж;

- екологічність та охорона навколишнього середовища - зниження потужностей електричних станцій та, як наслідок, зменшення викидів вуглекислого газу до атмосфери; нині тема глобального потепління та скорочення викидів вуглекисню $є$ дуже актуальною;

- енергоефективність - оптимізація та зниження споживання енергетичних потужностей за рахунок зниження споживання електричної енергіï [5, с. 126: 6, с. 140];

- фінансові переваги - споживачі електричної енергії мають можливість самостійно оптимізувати витрати електричної енергії та мати можливість подальшого планування витрат на експлуатацію розподільчих електричних мереж [2, с. 30 ; 4, с. $222 ; 9$, с. 7].

Авторами у [8, с. 17] було наведено переваги основних характеристик від упровадження інтелектуальних мереж SmartGrid:

\begin{tabular}{|l|l|}
\hline \multicolumn{1}{|c|}{ Характеристики } & \multicolumn{1}{|c|}{ Вигода } \\
\hline Самовідновлення & $\begin{array}{l}\text { Підвищення економії, надійності } \\
\text { та ефективності надлишку } \\
\text { енергї̈ }\end{array}$ \\
\hline $\begin{array}{l}\text { Мотивація, що } \\
\text { включає споживачів } \\
\text { електричної енергії }\end{array}$ & $\begin{array}{l}\text { Розумне використання } \\
\text { енергетичних ресурсів, } \\
\text { більш ефективна утилізація } \\
\text { відходів, має широкий діапазон } \\
\text { екологічної вигоди }\end{array}$ \\
\hline $\begin{array}{l}\text { Опір незаконному } \\
\text { втручанню }\end{array}$ & $\begin{array}{l}\text { Електрична мережа повинна } \\
\text { витримувати несанкціоновану } \\
\text { фізичну кібератаку }\end{array}$ \\
\hline $\begin{array}{l}\text { Забезпечення якості } \\
\text { електроенергї, якої } \\
\text { потребує 21-ше } \\
\text { сторіччя }\end{array}$ & $\begin{array}{l}\text { вапобігти зменшеннюб } \\
\text { обладнання, особливо за } \\
\text { використання цифрових } \\
\text { пристроїв }\end{array}$ \\
\hline $\begin{array}{l}\text { Погодження для } \\
\text { всіх поколінь та } \\
\text { функцій зберігання }\end{array}$ & $\begin{array}{l}\text { Різноманітні ресурси з «підключи } \\
\text { та грай» мають зв'язок різного } \\
\text { типу з опціями електричної } \\
\text { генерації та зберігання, } \\
\text { включаючи нові можливості } \\
\text { для більш ефективного, чистого } \\
\text { виробництва електричної енергії }\end{array}$ \\
\hline
\end{tabular}

\begin{tabular}{|l|l|}
\hline Можливий ринок & $\begin{array}{l}\text { Відкритий доступ до ринку } \\
\text { розкриває марні та неефективні } \\
\text { витрати та допомагає знищити } \\
\text { іх у системі, пропонуючи новий } \\
\text { вибір споживачам, такий як } \\
\text { «зелене» виробництво енергії. }\end{array}$ \\
\hline $\begin{array}{l}\text { Оптимізація активів } \\
\text { та ефективне } \\
\text { функціонування }\end{array}$ & $\begin{array}{l}\text { Бажане функціонування } \\
\text { за мінімізації витрат та } \\
\text { використання активів. }\end{array}$ \\
\hline
\end{tabular}

Неможливо не відзначити також і недоліки, які має технологія SmartGrid. Що стосується локальних проектів, то ці технології мають безперечні переваги. У європейських країнах у період iз 2000 року було втілено близько 100 таких проектів 3 використанням інтелектуальних мереж SmartGrid. Завдання, які поставали перед застосуванням таких проектів, у результаті було вирішено. Велика проблема міститься у спільній роботі існуючих енергетичних мереж та інтелектуальних мереж із використанням SmartGrid, зокрема йдеться про їх безаварійну роботу. Цей процес $є$ не до кінця вивченим. Отже, це завдання майбутнього - масштабне втілення інтелектуальних мереж SmartGrid, яке водночас $\epsilon$ досить недешевим заходом.

Також до суттєвих недоліків технологій SmartGrid під час їх втілення належать:

1. Знос основного електрообладнання систем електропостачання.

2. Недостатній рівень контролю споживання енергетичних ресурсів.

3. Значна величина втрат електричної енергії в системах електропостачання.

4. Недостатній рівень розвитку системи моніторингу споживання електричної енергії;

5. Все більш гострий дефіцит кваліфікованих кадрів в енергетичній галузі.

6. Підвищення обмежень щодо забруднення електричними станціями навколишнього середовища.

Але ці недоліки не $є$ підставою для припинення розроблення та втілення інтелектуальних мереж. Це $є$ повштохом для більш поглибленого аналізу та швидкої модернізації наявних електричних мереж із метою подальшого застосування технологій SmartGrid.

Висновки. Стаття присвячена новим тенденціям в електроенергетиці, зокрема розглянуто поняття інтелектуальних мереж SmartGrid. Це електричні мережі нового покоління, які мають велику кількість переваг, як було проаналізовано. Використання SmartGrid дасть змогу вирішити низку вагомих завдань за їх широкого впрова- 
дження та використання. Зокрема, «GRID 2030 A National Vision for Electricity's Second 100 Years» передбачає такі три етапи втілення та подальшого застосування технологій SmartGrid:

Етап I: мається на увазі прогрес у дослідженнях, розроблення та демонстрація передових технологій. Це також включає зусилля з уточнення та модернізації нормативно-правової бази.
Етап II: передбачає оборотність основного капіталу електричних активів та заміну на сучасні системи. Також включає місцеві та регіональні втілення концепцій і обладнання Grid 2030.

Етап III: містить розширення розгортання Grid 2030, починаючи 3 локального та регіонального рівнів, із подальшим виходом на національний та міжнародний ринки [3, с. 26].

\section{Список літератури:}

1. SEA инновации и эффективность, URL: https://www.sea.com.ua/oborudovanie-dlya-energetiki/smartgrids/

2. NIST Framework and Roadmap for Smart Grid Interoperability Standards, Release 2.0. Февраль 2012. Авторы: NIST (Национальный институт технологий и стандартизации, США), Государственный коммерческий департамент США. Концепция и дорожная карта по стандартам взаимодействия для SmartGrid.

3. "GRID 2030" A National Vision for Electricity's Second 100 Years, URL: https://www.energy.gov/sites/ prod/files/oeprod/DocumentsandMedia/Electric Vision_Document.pdf

4. Олійник Ю.С. Використання сонячних батарей у сучасних умовах / Ю.С. Олійник // Вчені записки Таврійського національного університету імені В.І. Вернадського. Серія: Технічні науки. Випуск 29 (68), № 2. 2018. С. 220-224.

5. Пантєлєєва І.В. Організаційні та технічні заходи з енергозбереження / І.В. Пантєлєєва // Збірник наукових праць Харківського національного університету Повітряних Сил. Харків, 2016. № 4. С. 125-127.

6. Шматько Н.М. Організація планування структурних змін у процесі розвитку промислового підприємства / Н.М. Шматько // Харківський національний економічний університет імені Семена Кузнеця. Випуск 4. С. 138-143.

7. Розумні електромережі або що таке SmartGrid, URL: https://eco-live.com.ua/content/blogs/rozumnielektromerezhi-abo-shcho-take-smart-grid

8. Укренерго: Розумні мережі (SMART GRID), URL: https://ua.energy/majbutnye-ukrenergo/smart-grid/

9. The National Energy Technology Laboratory "A vision for the Modern Grid", March, 2010. URL: https://netl.doe.gov/sites/default/files/Smartgrid/ASystemsViewoftheModernGrid_Final_v2_0.pdf

10. Повышение надёжности функционирования энергообъектов на основе усовершенствования программно-технического комплекса автоматизированной подсистемы аварийной и предупредительной защиты / П.Ф. Буданов, К.Ю. Бровко, П.В. Васюченко // Збірник наукових праць Харківського університету Повітряних Сил. Харків: Харків. ун-т Повітряних Сил імені Івана Кожедуба. 2016. Вип 48. С. 161-167.

\section{Oliinyk Yu.S., Lazarchuk L.M., Suk I.V. EMERGING TRENDS IN ENERGY}

When we use the term «intellectual networks», we mean new principles of the energy industry. The article discusses new trends in energy, namely the analysis of the main functions, advantages and disadvantages of intelligent adaptive networks of SmartGrid technology. The main purpose of intelligent networks is to ensure the reliable use of the networks, to extend the service life and to enable complete control of electrical appliances at a distance. In turn, the work of smart networks is based on information and communication technologies with the aim of further saving financial costs and increasing the reliability of electric networks without attracting additional energy resources. Modern energy systems should be modernized in accordance with new developments in the electricity sector. In the process of optimizing modern energy systems, it is possible to increase their efficiency, and there is no need for significant investments in the production, transmission and distribution of electrical energy. That is, it is possible to modernize the existing system to an intelligent one, thereby creating a fully integrated system of production, transmission, distribution and consumption of electrical energy, for example, by domestic consumers. The main groups of elements that make up knowledge networks are briefly discussed. Because SmartGrid's smart grids are fairly new and not widespread, their impact on the customer's electrical energy quality is not fully defined. The paper very briefly examines the impact of new smart grids on the quality of electrical energy. The article also focuses on the American approach to SmartGrid interoperability standards, expectations from the implementation of knowledge networks.

Key words: smart grids, grid reliability, electrical power, distribution grids, energy resources, renewable energy. 